\title{
EFL Teachers' Learning: Transitional Experiences from an Overseas Teacher Education Program to Japanese School Settings
}

\author{
Yuka Kurihara \\ Tokai University
}

Drawing on Vygotsky's sociocultural theory of mind as a conceptual framework, I discuss the nature of L2 teachers' learning to teach. In particular, I examine how EFL teachers who participated in overseas teacher education programs for professional development and returned to their native countries appropriated the pedagogical resources (hereinafter tools) presented in the programs into their own classroom instruction. EFL teachers' experiences are complex because their learning involves not only transferring the tools but also negotiating cultural boundaries between the two key contexts. Three secondary school English teachers from Japan, four U.S. program instructors, and two school administrators in Japan participated in this qualitative case study. The cases illustrated that an individual teacher's process of learning and the social world were intricately interwoven and influenced one another. The teachers also attempted to (re)construct new knowledge about ELT by negotiating crosscultural challenges. Implications for L2 teacher education programs are discussed.

本研究はヴィゴツキーの社会文化理論を枠組みに、英語教員の学びの本質を探る。英語を外 国語として教えているE F L 教員の中でも、特に海外で教員研修プログラムを経験し現在自国 で教える日本人教員が、研修で学んだツール(知識やスキル)を日本の現場でどのように自分の ものとして使用しているかについて調査した。教員は異なる環境へのツールの移行や、互いの 文化的側面を乗り越え折り合いをつけようとする、複雑な学びを経験する。この質的研究には、 中等教育の日本人英語教員 3 名、米国の教員研修プログラム関係者 4 名、そして日本の学校 管理職 2 名が参加した。結果、教員の学びとは、個々の学びの過程とその社会環境が密接に関

JALT Journal, Vol. 35, No. 1, May 2013 
係し互いに影響をもたらしながら起こつていることが明らかになった。また、教員は文化的差異 から生じる問題を解決する際、新たな英語教授アプローチを見出そうしていることも分かった。 最後に教員研修への応用を述べる。

I $\mathrm{n}$ the last 20 years, there has been a growing trend among EFL teachers toward participation in L2 teacher education programs in North American universities for professional development, after which they generally return to their native countries to teach. Given this circumstance, it is critical to understand the nature of EFL teachers' learning to teach, in particular, how they adapt the pedagogical resources (hereinafter tools) presented in the programs into their teaching settings. By using Vygotsky's sociocultural theory as a conceptual framework (Grossman, Smagorinsky, \& Valencia, 1999; Vygotsky, 1930s/1978), I investigated the transitional experiences of three Japanese EFL teachers newly trained in the U.S. as they reacclimated to their teaching situations in Japan. Because of its focus on the relationship of teachers with their contexts, Vygotsky's theory helps researchers better understand not only what sources contribute to change, but also how teachers deal with possibly competing goals and practices emphasized in various settings, and how they influence the contexts in which their learning to teach occurs. This qualitative case study, conducted for approximately 10 months, provides insights into how the teachers appropriated pedagogical tools in conjunction with their internal goals and histories, and how these are closely related to the social contexts where their learning to teach occurred. The results of this study may further allow us to better understand the influence of L2 teacher education.

\section{Review of the Literature}

\section{The Knowledge Base of L2 Teacher Education}

A central topic in recent $\mathrm{L} 2$ teacher education literature is what constitutes a professional knowledge base in the development of effective programs for English language teachers (Freeman \& Johnson, 1998; Grabe, Stoller, \& Tardy, 2000; Johnson, 2006; Johnston \& Goettsch, 2000; Yates \& Muchisky, 2003). Some consider that the core of the field should be based on a range of disciplines such as applied linguistics and second language acquisition (e.g., Yates \& Muchisky, 2003). They further emphasize that exposure to the subject matter should be central so as to enable L2 teachers to conduct informed teaching practice. However, since the late 1980s, this view has been challenged by constructivists who seek to understand the complex nature 
of L2 teachers' learning to teach by exploring their cognition (e.g., Woods, 1996). Drawing on sociocultural theory, scholars have further discussed the influential effects of the social world, such as schools, on teachers' learning to teach (e.g., Freeman \& Johnson, 1998).

Although studies from sociocultural perspectives have portrayed the dynamic nature of teachers' learning to teach, studies which investigate EFL teachers, in particular those who participate in overseas L2 teacher education programs, are scarce. Their learning experiences as they move from overseas programs to their native teaching settings need to be examined so that we can add new insights to the field of $\mathrm{L} 2$ teacher education.

\section{Vygotsky's Sociocultural Theory of Mind}

A strand of research in social science currently draws on Vygotsky's sociocultural theory of mind as its conceptual framework. This theory posits that people learn through their social engagements, which are embedded in historical, cultural, and social conditions (Lantolf \& Thorne, 2006; Morita, 2002; Vygotsky, 1930s/1978; Wertsch, 1991). The theory also emphasizes a critical role for the mediation of human activity by using physical and psychological tools (e.g., Ellis, Edwards, \& Smagorinsky, 2010). Tools mediate "social and individual functioning and connect the external and the internal, the social and the individual" (John-Steiner \& Mahn, 1996, p. 192).

Recent literature on teacher education in the L1 field explores the implications of Vygotsky's sociocultural theory (e.g., Ellis et al., 2010; Johnson, Smagorinsky, Thompson, \& Fry, 2003). This research reveals that teachers' learning to teach encompasses multiple activity settings, including university-level teacher education course work, field practicums, school contexts, and prior experiences, so their learning experiences may turn out to be distinctly different based on the relationships among these settings (e.g., Grossman et al., 1999). Each setting has its own cultural history throughout which members of the community have established specific goals that guide their actions within the setting (e.g., Lave \& Wenger, 1991). At the same time, because of their internal goals and histories, individual teachers are not just passive subjects who only reproduce "culturally valued concepts" (Edwards, 2010, p. 64).

Vygotsky's sociocultural theory also helps us recognize the roles of teachers' use of pedagogical tools which mediates their learning to teach (Grossman et al., 1999). Newell, Gingrich, and Johnson (2001) argued that rather than focusing on static internalization of knowledge transmitted during the 
course work, Vygotsky's theory provides a framework for examining teachers' "appropriation" of pedagogical tools, which, as Wertsch (1998) explains, is "the process ... of taking something that belongs to others and making it one's own" (p. 53). The scholarly discussion in these studies implies the need to explore L2 teachers' appropriation of pedagogical tools so that new insights can be added to existing teacher education research.

\section{The Study}

\section{Research Questions}

The main purpose of this study is to better understand the nature of EFL teachers' learning to teach by highlighting their appropriation processes within and across a variety of activity settings in which their learning to teach occurred. These settings included teacher education course work in the U.S., school settings in Japan, cross-cultural ELT issues, and teacher beliefs and backgrounds. A unique aspect of this present study is the examination of EFL teachers' transitional experiences as they cross from one setting to another. The study explores how teachers deal with possibly overlapping or competing values (or both), goals, and practices stressed in various activity settings and how they are being shaped by and shape the social settings. The following research questions were identified to achieve this aim:

1. What appropriation takes place when Japanese EFL teachers adopt pedagogical tools presented in the U.S. teacher education programs into their classroom instruction in Japan?

2. What sources and settings have influenced their appropriation?

\section{Method}

\section{Participants and School Settings}

The primary participants in this study were three Japanese senior high school teachers of English who had completed a 6-month or 1-year in-service teacher education program in the U.S. sponsored by the Japanese Ministry of Education, Culture, Sports, Science and Technology (MEXT). These teachers were selected from questionnaire respondents who expressed interest in the qualitative case study. I employed an "intensity sampling" strategy to learn as much as possible from the "information-rich cases that manifest the phenomenon of interest intensely" (Patton, 2001, p. 234). The teachers-Mr. Fujii, Mr. Suzuki, and Mr. Kato (pseudonyms) - were all born in Japan and received their formal education before or right after the implementation of 
EFL curriculum reform, which stresses the communicative-based pedagogy promoted by the Japanese government.

Fujii participated in a 6-month MEXT program in 1998 while at his first school of employment in northwestern Japan. Before, during, and after the program, he had various professional development opportunities inside and outside school. His current high school was located in a residential area. The students were "academically high" and most of them entered either universities or colleges upon graduation (Fujii interview, 19 Oct 2005).

Suzuki, who participated in a 12-month MEXT program in 1998-1999, transferred to his high school after the completion of the program. The school, located in a small rural area in the westernmost region of the main island of Japan, was designated as a Super English Language High School (SELHi). SELHi is a 3-year project promoted by the Japanese government in which each designated school has a responsibility to create an English curriculum and share it with the public (MEXT, 2004). According to his school's brochure, the main goal of the program was to develop highly practical English communication skills, especially self-expression, through English education and international understanding.

Kato attended a 6-month program in 2003. His high school was located in a large commercial city in western Japan and was characterized as a "historical school." According to the school principal, the school was implementing educational reform to prepare students for university examinations by letting them focus on specialized subjects.

Table 1 contains a summary of the participants and their school settings.

\section{MEXT Programs}

Another key setting of the participants' learning to teach was MEXT, which had shifted the goals of English education at the secondary school level from fact-oriented teaching to a communicative-oriented approach (MEXT, 1999, 2009). Accordingly, Japanese English teachers' professional development opportunities inside and outside Japan were greatly increased. For example, from 1998 through 2003, MEXT sent secondary school Japanese EFL teachers to a total of 12 state or private universities in the U.S. Individual universities created programs for the participants that satisfied the requirements proposed by MEXT (CIEE, 2003). The main goals of the programs were to improve Japanese teachers' English language skills, to better understand English language teaching methodology and its application, to broaden understandings of the various cultural and social aspects of the U.S. (and other countries), and to conduct research within the relevant EFL area (CLED, 1999, 2004). 
Table 1. Summary of Case Study Participants and School Settings

\begin{tabular}{|c|c|c|c|c|}
\hline \multicolumn{2}{|l|}{ Teacher } & Fujii & Suzuki & Kato \\
\hline \multicolumn{2}{|c|}{ Years of teaching } & 12 & 18 & 20 \\
\hline \multicolumn{2}{|c|}{ Degree } & BA in Linguistics & $\begin{array}{l}\text { BA in English } \\
\text { Literature }\end{array}$ & $\begin{array}{l}\text { BA in English } \\
\text { Language }\end{array}$ \\
\hline \multirow{2}{*}{$\begin{array}{l}\text { School } \\
\text { charac- } \\
\text { teristics } \\
\text { \& goals }\end{array}$} & $\begin{array}{l}\text { Previous } \\
\text { school }\end{array}$ & $\begin{array}{l}\text { English focused } \\
\text { course }\end{array}$ & $\begin{array}{l}\text { English specialized } \\
\text { course }\end{array}$ & Night school \\
\hline & $\begin{array}{l}\text { Current } \\
\text { school }\end{array}$ & $\begin{array}{l}\text { "Zest for living"; } \\
\text { University } \\
\text { entrance examina- } \\
\text { tions }\end{array}$ & $\begin{array}{l}\text { English focused } \\
\text { school; } \\
\text { University } \\
\text { entrance } \\
\text { examinations }\end{array}$ & $\begin{array}{l}\text { University } \\
\text { entrance examina- } \\
\text { tions }\end{array}$ \\
\hline \multicolumn{2}{|c|}{$\begin{array}{l}\text { Class size - } \\
\text { course title }\end{array}$} & $\begin{array}{l}24 \text { - } 11 \text { th grade } \\
\text { comprehensive } \\
\text { English; } \\
41 \text { - 11th grade } \\
\text { writing }\end{array}$ & $\begin{array}{l}39 \text { - } 12 \text { th grade } \\
\text { reading; } \\
9 \text { - } 12 \text { th grade } \\
\text { communication }\end{array}$ & $\begin{array}{l}27-12 \text { th grade } \\
\text { writing; } \\
27-12 \text { th grade } \\
\text { reading }\end{array}$ \\
\hline \multicolumn{2}{|c|}{ Responsibilities } & $\begin{array}{l}\text { English text } \\
\text { developer }\end{array}$ & $\begin{array}{l}\text { Head of the SELHi } \\
\text { program \& the } \\
\text { English depart- } \\
\text { ment; } \\
\text { Graduate student } \\
\text { in a distance } \\
\text { TESOL program in } \\
\text { England }\end{array}$ & $\begin{array}{l}\text { Manager of the } \\
\text { general affairs at } \\
\text { school }\end{array}$ \\
\hline
\end{tabular}

I chose two U.S. university MEXT-sponsored programs for this study: one 6-month and one 12-month; among the U.S. programs, they had the largest number of participants. These programs were held in university-affiliated English language schools within large research-based institutions. The course work offered in each program was institutionally planned. For example, one university stressed "language learning as a social construct" (Program coordinator interview, 8 Aug 2005). In the methodology class, the participants were required to read a textbook, The Practice of English Language Teaching by Jeremy Harmer, and other selected materials containing both practical (e.g., communicative activities) and theoretical knowledge, including an overview of learning theories and ELT approaches as well as concepts such as multiple intelligences. This course also had the participants observing foreign language classrooms in local middle and high schools, reflecting on their own learning, conducting a teaching project, and considering the 
potential application of communicative methods in their current teaching situations.

The other program emphasized "communicative methodology and taskbased learning" (Program coordinator interview, 13 Sep 2005). The reading texts required in the methodology course included How Languages are Learned by Patsy Lightbown and Nina Spada and Techniques and Principles in Language Teaching by Diane Larsen-Freeman. These textbooks contained both theoretical knowledge and practical ideas about ELT (e.g., an overview of various teaching methodologies, theories of L2 learning, and effective teaching techniques), and were used to develop lesson plans that adapted the required English textbooks in Japan to make them more communicative. Teachers also spent about one week in a local secondary school to observe ESL classes.

\section{Data Collection}

For the study, I employed a qualitative case study approach by triangulating multiple methods such as classroom observations, interviews, teacher reports, and questionnaires. Data were collected from August 2005 through May 2006. At the beginning of the study, questionnaires were administered to ascertain teachers' professional and academic backgrounds and to trace the influence of their past experiences on their ELT conceptions and practices. Another important set of data came from classroom observations of the primary participants' English teaching practices in each school setting in Japan and debriefings about my observations. These data were collected by visiting schools in October 2005 (two to three observations per teacher), and then through reports by the teachers on an approximately bimonthly basis (two to five reports per teacher). During the classroom observations, I took field notes of the participants' lessons and described the sequence of teaching activities in class, the content and approaches they used, and the interactions between students and teachers. To understand teachers' appropriation of pedagogical tools in more depth, audiotaped semi-structured interviews were also conducted at the beginning and the end of the study. In addition, four coordinators or instructors of the two MEXT programs and the school administrators in two of the schools where the teachers were employed each gave me permission to conduct an interview. All the data, except for the interactions with program hosts, were collected in Japanese. I also reviewed written documents obtained from the host programs such as course syllabi and the participants' reflective journals written in English, which were required by the host programs. 


\section{Data Analysis}

The processes of analyzing the qualitative case study involved seeking out salient patterns, categories, themes, and theories (Patton, 2001). Vygotsky's sociocultural perspectives on teacher education based on Grossman et al. (1999) also informed the data collection and analysis of this study. To build an empirically based case portrait of each teacher, I collaboratively coded the transcripts of the data with two peer debriefers.

The coding system was developed by following Johnson et al.'s (2003) study. The categories used in the data analysis were pedagogical tools, teaching areas, source of tools, and problems, which are derived from Vygotsky's sociocultural theory. Regarding pedagogical tools, two types, conceptual and practical, were used to understand the tool-mediated nature of instruction given by the teachers. Conceptual tools included problem-solving learning and collaborative learning; and practical tools included group work activities and Ministry-approved textbooks. Teaching areas in which the teachers employed particular tools included reading, writing, speaking/listening, language, and management. The source of tools was where the teachers had learned a particular tool, including prior experiences, school contexts, and the MEXT program. Finally, to understand the teachers' goal-oriented actions, I also identified what problems they had attempted to solve through their use of particular tools. The problems included students' learning, the application of pedagogical tools presented in the MEXT programs, and school goals at their teaching sites. Based on these results, tentative assertions about each teacher were tested. Finally, cross-case analysis was conducted to explain the similarities and differences across the teachers' cases.

\section{Findings}

\section{An Alignment Among Learning Settings: Fujii's Progress}

To the rank-ordering question on the questionnaire (see Appendix), Fujii responded that professional development opportunities inside and outside Japan and his teaching sites are the most influential factors that have affected his ideas about teaching. The interview and classroom observation data also suggest that, when he adopted the pedagogical tools presented in the MEXT program, these settings interactively mediated his appropriation of the tools.

Prior to the MEXT program, he was somewhat familiar with those concepts of sociocultural theory which value social interaction of learning. Referring to a pedagogical tool, language use in real-life situations, he explained from 
whom he had learned this concept of language teaching and how he used it in his practice:

I came to attempt to make learning relevant to students' real-life situations by discussing this with a professor in study meetings .... I started to include the idea before participating in the [MEXT] program .... it is perfectly natural to follow what Vygotsky suggests, so I often provide senior students with a theme of problem solving. (Fujii interview, 12 May 2006)

Other professional development opportunities which were found as the source of his pedagogical tools suggest Fujii had actively sought knowledge about ELT outside of the MEXT program. However, in problem-solving activities he had used before participating in the MEXT program, he had struggled with students' frequent avoidance of responses, their using "I don't know" (Fujii interview, 12 May 2006). He described his classroom instruction around that time as follows: "I taught English in my own way before the [MEXT] program and was unsatisfied every day" (Fujii interview, 19 Oct 2005).

The data suggest that he further developed an understanding of sociocultural theory, especially tool-mediated learning and social interaction, as a result of participating in the MEXT program. While observing one of the local classes, for example, he realized the significance of drawing for students' learning.

During the activity [drawing part of the story with peers], they were actively discussing it with each other by saying, "This mountain should be higher and that house should be bigger." I learned that participatory learning enabled quiet students to be actively involved in class. (Fujii interview, 12 May 2006)

As can be seen in this excerpt, Fujii appropriated the tool, visual and auditory aids, by considering a principle, peer learning, which he had learned in the MEXT program.

A challenge that Fujii and other teacher participants faced during the MEXT program, however, was English learning in EFL contexts where students have few opportunities to expose themselves to the target language beyond the classroom. Their reservations about whether the ideas about ESL teaching presented in the program would work in Japan allowed them to reconsider the issue and eventually they had new insights: 
There [in the US], English is being used outside the classroom .... The other participants and I always discussed what we could do to marry the two [ESL and EFL]. Then, an idea came up, or the only choice we thought we could have is that, due to limited English vocabulary and learning environments [in Japan], we should not think of English learning opportunities as a separate activity such as reading as just a reading class .... The expressions and ideas they learn in one setting are transferable to other contexts. (Fujii interview, 12 May 2006)

This excerpt suggests that the participants collaboratively developed the idea that the principle of integrating skills and courses across settings supports EFL students' learning because they can utilize and apply their knowledge in a range of new contexts.

Reflecting on the time when he returned from the program to his teaching site in Japan, he commented, "[Back at my] previous school, I tried out almost everything of what I had wanted to do and ideas that I had had in my mind during the program" (Fujii interview, 28 Aug 2005). My classroom observations also suggest that he intentionally had his students use the four English skills of reading, writing, listening, and speaking within each lesson and linked their work inside the classroom to outside (Field note, 19 Oct 2005). For example, to make grade 11 students' learning more effective in his comprehensive English class, he used a variety of reading materials about World Heritage sites as tools to think, and asked them to discuss with peers in English the good and bad points about a recently designated site in Japan. The main conceptual framework for using this group work included peer learning and the use of real-life situations. The primary goal of this activity was to fashion learning that helped students "discover what they share and what they come to newly realize" by exposing them to ideas that are different from their own (Fujii interview, 12 May 2006). Referring to eishaku [language training] in the same lesson, Fujii further explained how this practical technique also helped his students connect their language skills gained in the practice with the problem-solving activity in which they engaged:

By having my students repeatedly read [texts] aloud, I want to provide them with training opportunities within 50-minute lessons .... Through such activities, I want my students to learn and remember as much useful English as possible. Then, students can borrow the language from there and connect the knowledge to their actual utterances. I learned this idea in 
study group meetings in Japan [after the MEXT program] and keep adapting it myself. (Fujii interview, 12 May 2006)

Fujii's understanding of these conceptual and practical tools evolved as he realized, reflected upon, and tested the problems about his teaching practices (e.g., few opportunities for students to use English beyond the classroom in Japan) by making use of the activity settings available to him such as the MEXT program, his school sites, and study meetings. Through this problemsolving process, he eventually constructed new knowledge about ELT.

\section{From Self-Serving to Goal-Oriented Teaching: Suzuki's Negotiation}

In the rank-ordering portion of the questionnaire (see Appendix), Suzuki responded that two activity settings, professional development opportunities (in particular the MEXT program) and his teaching sites at schools, had influenced his ideas about teaching the most. However, the findings of the case study suggest that multiple activity settings interactively mediated his appropriation of the pedagogical tools. For example, his educational background as an EFL learner also seemed to be influential in his instructional decision making. He explained:

During my 3 years at high school, I studied English so hard. Right after entering university, however, I stopped. In summer I planned to take the STEP Eiken [English proficiency exam] and prepared for that. But I found I did not remember any words in the vocabulary book I had studied just 3 months before. The reason why is because I did not use what I studied. (Suzuki interview, 23 Mar 2006)

This excerpt suggests that all the efforts he had made to pass university entrance examinations (e.g., memorizing words) when he was a high school student did not contribute to his later English learning, but shaped his English teaching principles. That is, the actual use of English knowledge is indispensable for EFL learning.

This conceptual principle seemed to be further reinforced in the MEXT program, in which he was exposed to instructional techniques in reading and listening, including pre- and postreading activities. The following conversation between Suzuki and me illustrates how his educational background and the pedagogical tools newly acquired in the program were eventually connected: 
Kurihara: You noted in your report that the idea about learning English through expressing what you learned came from not only your own experiences in the past but also an influence from Dr. Lidgley (pseudonym) in the MEXT program. Could you elaborate on that?

Suzuki: I learned about receptive skills, reading and listening [in the methodology class]. For example, reading includes pre-, while-, and postreading. I learned that, instead of completing [reading] just with [while-] reading, it is good to include a follow-up activity .... The idea [about actual use of English] came from this experience. (Suzuki, Report 4, 2 Feb 2006)

These comments suggest that Lidgley's methodology course had enabled Suzuki to realize the significance of using these practical tools (e.g., postreading activities) grounded in the main conceptual framework, actual use of language.

His retrospective interviews, however, suggest that when Suzuki made the transition from the MEXT program to his teaching site in Japan, he experienced moments of disappointment and challenges:

Around that time [right after returning to my teaching site], I mainly taught reading classes. I had my students work on very conventional university-driven workbooks [assigned to the class] and included what I called Culture Time in the interval. During the Culture Time, I let them listen to real news and music, and showed TV commercials .... It was like making use of whatever I had learned in the MEXT program .... After my students entered the 3rd year, I realized that their reaction toward my teaching became negative .... Last year, I struggled with it. I'm afraid my rambling instruction caused this consequence. (Suzuki interview, 27 Oct 2005)

This excerpt suggests that for the first few years after the completion of the MEXT program, Suzuki's inclination toward EFL teaching was to try out "whatever [he] had learned in the MEXT program" and he eventually experienced dismay about his "rambling instruction." The 4th year after the program, however, he became a coordinator of the SELHi project and started to create the English curriculum with his colleagues. This collaborative work eventually allowed him to see the benefits of using pedagogical tools that he 
had learned in the MEXT program to develop more sequential teaching approaches. Reflecting on the framework of reading and listening instruction learned from Lidgley, he commented thus:

I am now able to teach by taking the future of my students into consideration. This includes what would it be after a 1-hour lesson of a three-credit course as a short-term consideration, and also after 1 year and 3 years as a long-term consideration .... It was after I started to make the syllabi of English courses with other English teachers [that I had this vision]. (Suzuki interview, 29 Aug 2005)

This excerpt suggests that Suzuki transformed his professional self from a teacher who was self-serving with his instruction to a teacher who takes students' learning into consideration by framing his instruction with teaching goals in mind.

Throughout the study, Suzuki consistently distinguished teaching to examinations and teaching beyond examinations, which he and his colleagues attempted to conduct at his school. For example, in his 12 th grade reading class, after he had explained English grammar points (idioms) to students, which according to him often appear on university entrance examinations, he asked the students to write English sentences of up to 20 words using each idiom as a postreading activity. Students were required to write sentences relevant to their own lives (Suzuki, Report 5, 9 Feb 2006). Suzuki explained the reasons behind this activity:

[Even] if students have finished the lesson by learning the grammar points in the workbook, they will not have situations where they can actually use what they learned. When they express English with the knowledge, it finally becomes their own. I offer my lessons based on this idea. (Suzuki, Report 5, 9 Feb 2006)

Suzuki appropriated a pedagogical tool learned in the MEXT program, a postreading activity, to facilitate students' language learning. When using the tool, he took into consideration the goal of the SELHi curriculum (to develop students' self expression), the responsibility to successfully send students to universities, and his desire to have them actually use English in the lessons. 


\section{"Going Back to My Original Teaching": Kato's Challenges}

To the rank-ordering question in the questionnaire (see Appendix), Kato responded that his learning experience in the MEXT program is what has most influenced his teaching ideas. However, his appropriation of the pedagogical tools presented in the program involved great challenges because of seemingly incompatible goals across and within his main activity settings. These settings included his pre-training experiences as an EFL teacher, the MEXT program, and his school culture.

In the 12th grade Writing and Reading lessons I observed, for example, Kato prepared a worksheet and had his students fill in the blanks with answers to workbook questions, key grammar points he had explained, and the Japanese translations of English words or expressions (Field note, 17 Oct 2005). He called this activity sagyo [performance] and explained the possible sources of his instructional decision to use this tool:

There are many students who do not think of English as being necessary and who are not very good at it, so I could not expect effective learning results from lecture-styled teaching by giving the students lots of knowledge. As a result, I decided to use an effective learning method that I had used when I worked at a night school before .... To get the information they wanted to know about the story, they did translating sagyo by actively using a dictionary. (Kato, Report 1, 28 Oct 2005)

As can be seen in this excerpt, Kato's professional background prior to the MEXT program, especially working at a night school, as well as his concerns about students' learning seemed to play an important role in guiding his instruction.

During the MEXT program, this previously shaped teaching perspective appears to have had a significant effect on his learning and understanding of what was presented in the program. The following retrospective interview suggests that his experiences in the ESL coursework in the program further reinforced his belief about his EFL approach to sagyo:

In the [ESL] class, we did not learn grammar only from a grammar book, but learned through actual writing, actual reading, and actual presentations. By doing so, [we found that these practices] gradually became ingredients .... It is not just teachers' lecturing but students' doing actual sagyo .... Through 
doing sagyo over and over, students will be able to come to use it [English]. (Kato interview, 27 May 2006)

This excerpt suggests that Kato carried over his prior knowledge about sagyo to the MEXT program and integrated it with another new tool, which he called "actual practice of language over and over" (Kato interview, 27 May 2006).

When he made the transition from the MEXT program to his teaching site in Japan, Kato experienced feelings of being torn between the seemingly incompatible goals of the two settings, his school and the MEXT program:

Right after I came back from the U.S., . . . I did a group work activity in my class once, but stopped using it .... In the end, group work did not work well in Japan due to the reality of university entrance examinations. I discussed it [group work] in my research project during the program, but what I wrote in the project and the teaching instruction to the exam do not match well. (Kato interview, 17 Oct 2005)

This excerpt suggests that once Kato resumed EFL teaching in Japan, his school became a key activity setting that affected his appropriation of the pedagogical tools. According to Kato, "the highest expectation of [my] school is probably to successfully prepare students for university entrance examinations" (Kato interview, 27 May 2006). This ultimate goal eventually compelled him to focus on "what would be useful in [his] school and what would be appropriate to meet [his] school expectations" (Kato interview, 17 Oct 2005). As a result, he selectively used pedagogical tools such as "sagyo over and over," because these activities allowed him to fulfill his professional responsibilities at the school and his desire to try out the pedagogical tools he had learned in the MEXT program.

Kato eventually developed a sense of doubt about his own teaching approach. For example, reflecting on the last 2 years since he returned from the MEXT program to his teaching site, he commented on the reshaping of his professional self:

I returned to Japan with a feeling that I wanted to conduct lessons using this kind of practice and that kind of practice. I also thought what teaching I could offer to my students with the English skills I had developed. But the environment surrounding me has not changed, so [my instruction] is gradually going back to my original teaching. (Kato interview, 17 Oct 2005) 
Throughout the study, I found that Kato frequently expressed concerns about the impact that his instruction may have on his students' learning. Reflecting on his 12th grade reading lessons, he noted the following:

As long as I offer a lesson and give them an exam, my students can get points, but to be able to get points has been a priority rather than feeling fulfilled through lessons .... I am worried that I am creating students who patiently study English even though they suffer and hate to learn it. (Kato, Report 2, 17 Jan 2006)

Although Kato expressed a positive point about participating in the MEXT program in that he had gained confidence in his English language skills, these excerpts suggest that he felt disappointed when he realized that the established school goals did not allow him to try out the tools he had learned in the program. Unlike the other two participants, because Kato could not trial what he had learned in the MEXT program, he could not thereby reflect on his pedagogical application inside or outside school. Perhaps the lack of these opportunities was partly due to his commitment as a manager in the general affairs department which "took most of his professional time" and "made it difficult for [him] to design the curriculum of English education as a main English teacher for a certain grade" (Kato interview, 17 Oct 2005).

\section{Discussion}

This study illustrated how three Japanese EFL teachers took various paths in appropriating pedagogical tools as they made the transition from a U.S. teacher education program to their teaching sites in Japan. The results suggested that the teachers' appropriation of tools depended on their histories and the professional experiences they brought to the given contexts, as well as their relationship with social settings, including the MEXT program (e.g., what pedagogical tools the program made available to them, what they took from the program), school culture (e.g., goals, students' needs), and other professional development opportunities (e.g., study group meetings). This finding follows Vygotsky's sociocultural theory that humans' cognitive development is simultaneously unique to individuals and socially constructed (e.g., John-Steiner \& Mahn, 1996). Thus, as Morita (2002) contends, it is unproductive to treat individuals and social contexts as separate entities.

The goals, values, and practices emphasized in the settings overlapped and competed across and within the settings in dynamic ways, so they affected 
the teachers' appropriation processes. Although all the teachers, to greater or lesser extents, experienced moments of both making progress and having challenges, when there was an alignment of goals and practices stressed in the settings, the teachers tended to be able to draw on what they had learned from the MEXT program (see Grossman et al., 1999 for a similar discussion). However, in cases of competing goals and practices among the settings, they appeared to encounter challenges in appropriating the tools into their teaching sites (see Grossman et al., 1999 for a similar discussion).

Because the teachers' learning involved crossing cultural boundaries, they attempted not only to transfer the instructional tools but also to negotiate various demands emphasized in the key settings in order to meet the needs of their teaching sites. The challenges they faced included integrating institutionally and nationally established cultural norms of what is good learning and their newly constructed assumptions about English teaching and learning. However, the case study data suggest that the teachers did not simply adopt one cultural aspect of English teaching (e.g., the group work promoted in the U.S. MEXT program) and ignore another one (e.g., university entrance examinations considered to be important in schools in Japan), but they attempted to negotiate the problems derived from the different sets of values in the two settings (see Morita, 2002 \& 2004, for similar discussions about L2 learners' identity construction). It was through this problem-solving process that the knowledge they gained in the MEXT program, the responsibilities they had in their teaching sites in Japan, and their own goals for classroom instruction became intertwined. Two participants eventually constructed pedagogically stronger and more context-sensitive ELT approaches. Fujii and Suzuki attempted to negotiate the differences and eventually adapted some of the tools presented in the MEXT program in ways that worked in their own teaching contexts. Constraints they faced in light of cross-cultural boundaries proved "a positive set of limitations that provide[d] the structure for productive activity" (Grossman et al., 1999, p. 7). Teachers are not only passive recipients of culturally valued goals and practices in given contexts but also actors having an impact on them (Edwards, 2010).

The findings also suggested that the teachers' appropriation processes involved constructing their professional selves within the settings in which their learning to teach occurred. A theme that frequently emerged in the three teachers' cases was "the reciprocal relationship between their appropriating the tools and their sense of professional selves" that developed as they applied the tools presented in the MEXT program to their classroom instruction in Ja- 
pan (G. E. Newell, personal communication, 14 Mar 2007; and for L2 learners' negotiating identities, also see Morita, 2002, 2004). For example, Kato, who struggled with the incongruity between the goals of his school and his desire to use the tools learned in the program, stopped trying out some of the tools and eventually developed a sense of doubt about his own teaching approach. This relatively negative professional self that he constructed through doubting his own teaching seemed to make it more difficult for him to appropriate the tools in the school culture. In contrast, Suzuki, who had also found himself torn between the two settings for the first few years, collaboratively developed the English curriculum with his colleagues and began to enthusiastically appropriate the pedagogical tools presented in the program into his classroom lessons. Around that time, his professional self was transformed from a single player with "self-serving instruction" to a team player with a more coherent sequence of teaching practices. That broader social relationships and identities constantly interact and mutually shape one another is also something Lave and Wenger (1991) discuss.

\section{Implications}

This study offers implications for L2 teacher education regarding how to foster teachers' appropriation processes and eventually develop effective teacher education programs for EFL teachers. First, rather than assuming that providing teachers with training readily promotes new ways of thinking and behavior, teacher educators need to consider the teaching conceptions and practices teachers have constructed and how these elements interact with other elements in their learning contexts (Ellis et al., 2010; Grossman et al., 1999; Newell et al., 2001; and for a similar discussion, see Morita, 2002, 2004) such as school culture, teacher education, cross-cultural negotiation, and professional self. Viewing teachers' learning as a complex process involving various sources and settings allows us to provide additional insights into the discussion about what constitutes a professional knowledge base when developing effective programs. That is, the effects of teacher education need to be viewed with other relevant activity settings in which teachers' learning to teach occurs because of the interconnected relationship between teacher education programs and other elements in their learning contexts (see Grossman et al., 1999 for a similar discussion).

Second, however, teacher education programs can play a critical role in (re)shaping teachers' teaching conceptions and practices if they provide teachers with activity settings to examine their beliefs about EFL teaching and learning, understand pedagogical tools, try out the tools in their teaching 
sites, and reflect on their pedagogical application. In this study, the teachers' learning seemed to be promoted when they had these opportunities in the processes of appropriating the tools.

The findings of this study further suggest that ongoing access to the appropriation of tools after teacher education programs is necessary to help teachers deal with competing goals and practices stressed in various learning settings. Such continuing access would allow them to better understand the instructional challenges they are faced with and critically examine their classroom practices. This would eventually result in better ELT instruction for their students.

\section{Acknowledgements}

I would like to thank the Japanese secondary school EFL teachers who participated in this study. I am also thankful to Keiko Samimy, George Newell, and Kathleen Romstedt for their support throughout this study. My gratitude also goes to Naoko Morita who inspired me to conduct research.

Yuka Kurihara is an associate professor in Center for Liberal Arts Education at Tokai University. Her research interests include L2 teacher education, educational psychology, and L2 literacy.

\section{References}

CIEE (Council on International Educational Exchange). (2003). Ministry of EducationJapanese Teacher Program: Campus Consultation 2003. Boston, MA: CIEE.

CLED (Georgetown University Center for Language Education and Development). (2004, 1999). Japanese Ministry of Education study in the USA, one year teacher training program at Georgetown University, Center for Language Education and Development. Washington, DC: Georgetown University.

Edwards, A. (2010). How can Vygotsky and his legacy help us to understand and develop teacher education? In V. Ellis, A. Edwards, \& P. Smagorinsky (Eds.), Culturalhistorical perspectives on teacher education and development (pp. 64-77). New York: Routledge.

Ellis, V., Edwards, A., \& Smagorinsky, P. (2010). Introduction. In V. Ellis, A. Edwards, \& P. Smagorinsky (Eds.), Cultural-historical perspectives on teacher education and development (pp. 1-10). New York: Routledge.

Freeman, D., \& Johnson, K. E. (1998). Reconceptualizing the knowledge-base of language teacher education. TESOL Quarterly, 32, 397-417. 
Grabe, W., Stoller, F. L., \& Tardy, C. (2000). Disciplinary knowledge as a foundation for teacher preparation. In K. J. Hall \& G. W. Eggington (Eds.), The sociopolitics of English language teaching (pp. 178-194). Clevedon, UK: Multilingual Matters.

Grossman, P. L., Smagorinsky, P., \& Valencia, S. (1999). Appropriating tools for teaching English: A theoretical framework for research on learning to teach. American Journal of Education, 108, 1-29.

Johnson, K. E. (2006). The sociocultural turn and its challenges for second language teacher education. TESOL Quarterly, 40, 235-257.

Johnson, S. T., Smagorinsky, P., Thompson. L., \& Fry, G. P. (2003). Learning to teach the five-paragraph theme. Research in the Teaching of English, 38, 136-176.

John-Steiner, V., \& Mahn, H. (1996). Sociocultural approaches to learning and development: A Vygotskian framework. Educational Psychologist, 31, 191-206.

Johnston, B., \& Goettsch, K. (2000). In search of the knowledge base of language teaching: Explanations by experienced teachers. The Canadian Modern Language Review, 56, 436-468.

Lantolf, J. P., \& Thorne, S. L. (2006). Sociocultural theory and the genesis of second language development. Oxford: Oxford University Press.

Lave, J., \& Wenger, E. (1991). Situated learning: Legitimate peripheral participation. New York: Cambridge University Press.

MEXT (Ministry of Education, Culture, Sports, Science and Technology). (2004). Heisei 18-nendo sūpā ingurisshu rangēji haisukūru (SELHi) no kettei ni tsuite [Decision about Super English Language High Schools (SELHi) in 2006]. Retrieved from http://www.mext.go.jp/b_menu/houdou/18/04/06041201.htm

MEXT (Ministry of Education, Culture, Sports, Science, and Technology). (1999, 2009). Kōtōgakkō gakushū yōryō kaisetsu [The explanation of the course of study for upper secondary school]. Tokyo: MEXT.

Morita, N. (2002). Negotiating participation in second language academic communities: A study of identity, agency, and transformation (Unpublished doctoral dissertation). The University of British Columbia, Vancouver, Canada.

Morita, N. (2004). Negotiating participation and identity in second language academic communities. TESOL Quarterly, 38, 573-603.

Newell, G. E., Gingrich, S. R., \& Johnson, B. A. (2001). Considering the contexts for appropriating theoretical and practical tools for teaching middle and secondary English. Research in the Teaching of English, 35, 302-343.

Patton, Q. M. (2001). Qualitative research and evaluation methods. Thousand Oaks, CA: Sage. 
Vygotsky, L. S. (1978). Mind in society: The development of higher psychological processes. In M. Cole, V. John-Steiner, S. Scribner, \& E. Souberman (Eds.), Cambridge, MA: Harvard University Press. (Originals works published 1930s)

Wertsch, J. V. (1991). Voices of the mind: A sociocultural approach to mediated action. Cambridge, MA: Harvard University Press.

Wertsch, J. V. (1998). Mind as action. New York: Oxford University Press.

Woods, D. (1996). Teacher cognition in language teaching. New York: Cambridge University Press.

Yates, R., \& D. Muchisky. (2003). On reconceptualizing teacher education. TESOL Quarterly, 37, 135-147.

\section{Appendix}

\section{Part III Teaching Principle}

Questionnaire - Teachers' Post-Overseas Training Experiences (Relevant Section of Longer Questionnaire)

I would like to know your daily English teaching practices and beliefs or principles in teaching. Please provide your answers in the space below each question in this section.

1a) First, I would like to know your typical English lesson. Please describe how you recently go about teaching English in class. Please try to be specific.

1b) Please explain why you teach that way. Please be sure to include your own beliefs (e.g., principles, values) as a teacher.

2. Please recall your formal educational experiences in learning and teaching English. To what extent do you think each of the following experiences has affected your beliefs as English teacher? Please circle the number that best describes the degree of affect with each statement.

Degree of affect

4. Affected me a great deal

3. Affected me to some extent

2. Affected me only a little

1. Did not affect me at all

a. Secondary school courses when you were a student 
b. Undergraduate (graduate, if any) level (teacher education) courses

$\begin{array}{llll}4 & 3 & 2 & 1\end{array}$

c. Teaching practicum conducted during the undergraduate teacher education program

d. Teacher development opportunities other than No. 2 (e.g., domestic shortterm training, overseas MEXT programs, $\begin{array}{llll}4 & 3 & 2 & 1\end{array}$ conferences)

e. Teaching experiences at school environments (e.g., school, students' parents', and/or administrators' expectations, colleagues)

f. National policies described in "The Course of Study"

$\begin{array}{llll}4 & 3 & 2 & 1\end{array}$

$\begin{array}{llll}4 & 3 & 2 & 1\end{array}$ $\begin{array}{llll}4 & 3 & 2 & 1\end{array}$ $\begin{array}{llll}4 & 3 & 2 & 1\end{array}$

3. Please describe the most influential event(s) (including any other life experiences) that have/has affected your beliefs as an English teacher. 